\title{
PENGENDALIAN HAMA KELAPA SAWIT (ELAIES GUINESSIS JACQ) DI PT. BUMI PALMA LESTARI, BAGAN JAYA KECAMATAN ENOK KABUPATEN INDRAGIRI HILIR - RIAU
}

\author{
Hidayati ${ }^{1}$ \\ 'Jurusan Pertanian, Fakultas Pertanian, Universitas Islam Indragiri \\ Email: aida87794@gmail.com
}

\begin{abstract}
Oil palm (Elaeis guineensis jacq) is a tropical plant that is thought to have originated from Nigeria (West Africa) because it was first discovered in the wilderness of that country.

Oil palm was first introduced to Indonesia in 1848, brought from Maurtius and Amsterdam by a Dutch citizen. There are two swit coconut seeds from the two places each and the same leaves are planted in the Botanical Gardens. Bogor (s'Lands plantenium Buiten Zorg) is still alive and is believed to be the ancestor of oil palm in Southeast Asia (Hadi, 2004). The technical aspect is the part where all work on the plantation is followed by the author and carried out with company employees, here the author carries out the tasks instructed by the assistant and foreman and is responsible for all the tasks, or tasks that the author does. Pests are organisms that are considered harmful and unwanted in human daily activities. The pests found in PT. Bumi Palma Lestari Persada is located in Bagan Jaya Village, Enok District, Indragiri Hilir Regency, Riau Province. Are: Pests Horn Beetle (Oryctes rhinoceros),. Fire Caterpillars, Termite Pests.
\end{abstract}

Keywords: oil palm pests

\begin{abstract}
Abstrak
Kelapa sawit (Elaeis guineensis jacq) merupakan tumbuhan tropis yang diperkirakan berasal dari Nigeria (Afrika Barat) karena pertama kali ditemukan dihutan belantara Negara tersebut. Kelapa sawit pertama kali di introduksikan ke Indonesia pada tahun 1848, dibawa dari Maurtius dan Amsterdam oleh seorang warga Belanda. Bibit kelapa swit yang berasal dari kedua tempat terebut masing-masing berjumlah dua batang dan poada taun yang sma ditanam di Kebun Raya Bogor (s'Lands plantenium Buiten Zorg) hingga saat ini pohon tersebut masih hidup dan yakini sebagai nenek moyang kelapa sawit Di Asia Tenggara (Hadi, 2004). Aspek tekis adalah bagian di mana semua pekerjaan yang ada di perkebunan tersebut di ikuti oleh penulis dan dilaksanakan bersama karyawan perusahaan, disini penulis menjalankan tugas yang di intruksikan oleh asisten dan mandor serta bertanggung jawab atas semua tugas, atau pu tugas-tugas yang penulis lakukan. Hama adalah organisme yang dianggap merugikan dan tak diinginkan dalam kegiatan sehari-hari manusia.Hama yang terdapat di PT. Bumi Palma Lestari Persada terletak di Desa Bagan Jaya Kecamatan Enok Kabupaten Indragiri Hilir Provinsi Riau. Adalah : Hama Kumbang Tanduk (Oryctes rhinoceros), . Hama Ulat api, Hama Rayap.
\end{abstract}

Kata kunci: Hama kelapa sawit

\section{PENDAhuluAN}

Kelapa sawit (Elaeis guineensis jacq) merupakan tumbuhan tropis yang diperkirakan berasal dari Nigeria (Afrika Barat) karena pertama kali ditemukan dihutan belantara Negara tersebut. Kelapa sawit pertama kali di introduksikan ke Indonesia pada tahun 1848, dibawa dari Maurtius dan Amsterdam oleh seorang warga Belanda. Bibit kelapa swit yang berasal dari kedua tempat terebut masing-masing berjumlah dua batang dan poada taun yang sma ditanam di 
Kebun Raya Bogor (s'Lands plantenium Buiten Zorg) hingga saat ini pohon tersebut masih hidup dan doiyakini sebagai nenek moyang kelapa sawit Di Asia Tenggara (Hadi, 2004).

$2 . \quad$ Perkebunan kelapa sawit dihasilkan untuk menghasilkan tandan buah segar (TBS) dan selanjutnya diolah menjadi minyak kelapa sawit, yaitu minyak yang berasal dari daging buah yang disebut (CPO) dan minyak dari ekstraksi inti buah disebut (PKO) dari kedua minyak tersebut disebut minyak mentah.Menurut paham (2006) panen adalah suatu kegiatan memotong tandan buah kelapa sawit yang memenuu kriteria matang panen, kemudian mengangkat dan mengumpulkannya bersama brondolan ketempat pengumpulan hasil (TPH) untuk selanjutnya diangkut kepabrik pengolahan kelapa sawit (PKS) tanpa menimbulkan kerusakn pada tanaman. Lubis (1992), mengatakan bahwa kegiatan panen merupakan crmin berhasil atau tidaknya kegiatan perawatan tanaman yang dilakukan suatu perkebunan kelapa sawit. Kegiatan pemupukan misalnya, pemupukan yang tidak tepat dapat menyebabkan tanaman berproduksi kurang optimal. Sebaiknya apabila pemupukan dilaksanakan dengan baik sesuai dengan komposisi kebutuhan, maka kelapa sawit akan berproduksi secara baik.

Sedangkan Anonim (1997), memberi penjelasan, bahwa keberhasilan kegiatan panen dan transportasi panen dipengaruhi oleh faktor Sumber Daya Manusia. Dalam hal ini perusahaan sebagai wadah (Organisasi) orangorang yang mempunyai orientasi dan tujuan yang baik bersifat material maupun non material. Dari perkumpulan tersebut akan terpilih atau tercipta suatu pumpinan dan dipimpin (Bawahan). Dari masing-masing tingkatan tersebut apabila bekerja pada koridor yang telah ditetapkan maka tujuan tersebut dapat tercapai. Kelapa sawit sangat rakus dengan unsur hara, kondisi ini dapat dicegah atau diperbaiki dengan menambah unsur hara kedalam tanah dengan melaksanakan pemupukan. Menurut novizan (2002) ada 16 unsur hara yang di butuhkan oleh tanaman untuk menunjang kehidupannya, jika tiga di antaranya di serap melalui udara yaitu Karbon (K) Oksigen (O), dan Hidrogen $(\mathrm{H})$ dan 13 unsur hara yang lainnya diserap tanaman melalui tanah yaitu Nitrogen $(\mathrm{N})$, Phospor ( $P$ ), Kalium (K), Kalsium (Ca) Magnesium $(\mathrm{Mg})$, Sulfur (S), Besi (Fe), Mangan (Mn), Boron (B), Seng ( $\mathrm{Zn})$, Tembaga (Cu), Molibdenum (Mo), dan Khorl $(\mathrm{Ci})$, ketoga belas unsur hara tersebut dapat digolongkan menjadi dua bagian yaitu unsur hara nakro dan unsur hara mikro. Unsur hara makro terdiri dari unsur hara $\mathrm{N}, \mathrm{P}, \mathrm{K}, \mathrm{Ca}, \mathrm{B}, \mathrm{Mg}$, dan, $\mathrm{S}$, sedangkan unsur hara mikro terdiri dari unsur $\mathrm{Zn}, \mathrm{Fe}, \mathrm{Cu}, \mathrm{Mn}, \mathrm{Mo}$, Dan Ci.
Unsur hara makro adalah unur hara yang harus terpenuhi atau dibutuhkan tanaman dalam jumlah banyak, unsur hara mikro adalah unsur hara yang dibutuhkan oleh tanaman dalam jumlah sedikit namun sangat berpengaruh terhadap tanaman. Untuk menunjang pertumbuhan tanaman agar dapat mengahsilkan buah sawit yang berkualitas dan produksi yang maksimal harus dilakukan penambahan unsur hara pada tanah agar cukup tersedia pada tanaman dengan melakukan pemupukan.

Kelapa sawit termasuk produk yang banyak diminati oleh investor karena nilai ekonomis yang tinggi, para investor mengivestasikan modalnya untuk membangun perkebunan dan pabrik pengolaan kelapa sawit. Potensial areal perkebunaan Indonesia masih terbuka luas untuk tanaman kelapa sawit .perkembangan perkebunaan tidak hanya diarahkan kepada sentral produksi seperti Sumatra dan Kalimanta, tetapi daerah potensi pengembangan seperti Sulawesi dan irian jaya terus dilakukan, data dilapangan menunjukan kecenderungan peningkatan luas areal perkebunan kelapa sawit khususnya perkebunan rakyat, pertumbuhan perkebunan rakyat pada periode 30 tahun terakhir mencapai $45,1 \%$ per tahun dan areal perkebunan negara tumbuh $68 \%$ per tahun. Di Indonesia tanaman kelapa sawit memilki arti penting bagi pembangunan perkebunan nasional. selain menciptakan kesempatan kerja yang memberikan kesejahteraan masyarakat, dan juga sebagai sumber devisa negara .

pengemabangan perkebunan kelapa sawit untuk mencapai kestabilan produksi peningkatan produktifitas harus diikuti dengan peningkatan pemilaharaan pada kelapa sawit adalah"pengendalian hama" . seperi halnya tanamn lain serangan ama dan sangat berbahaya apabila tidak dikendalikan. tindakan pemeliharaan sangatlah penting dalam usaha peningkatan produksi sehingga perlu dilakukan secara benar ( Sastrosayono, 2002).

Hama adalah organisme yang mengganggu tanaman budidaya sampai ambang batas ekonomi. pada perubahan lingkungan seperti pembukaan kawasan lahan baru untuk pembangnan perkebunan akan mengakibatkan terjadinya perubahan hewan tertentu dan beberapa hewan lain akan tersisih, sementara jenis hewan yang lainnya justru dapat berkembang dan akhirnya mencapai populasi yang dapat menimbulkan kerusakan atau terjadinya hama (Endah, 2002). menrut Risza (1994), pengendalian hama adalah usaha untuk mengurangi atau menurunkan populasi hama sampai batas ambang ekonomi sehingga tidak merugikan secara ekonomis dan tidak melampaui batas kritis keseimbangan alam. 


\subsection{Tujuan}

Adapun tujuan dari magang ini adalah :

1. Meningkatkan kemampuan profesional penulis dalam memahami dan menghayati proses kerja secara nyata.

2. Penulis diharapkan dapat melaksanakan kegiatan atau tanggung jawab setara sebagai buruh haruan lepas, mandor dan sampai dengan asisten afdeling.

3. Melatih keterampilan bidang tehknis lapangan maupun bidang manejemen tenaga kerja serta melatih bersisoalisasi dengan masyarakat.

4. Mempelajari dan memperdalam pengetahuan dan keterampilan khususnya mengenai panen dan transportasi panen kelapa sawit.

\section{TINJAUAN PUSTAKA}

\section{KEADAAN LOKASI MAGANG}

\section{2.1 Sejarah Umum Perusahaan}

6. Perkebunan Sinarmas Bumi Lestari Estate adalah salah satu dari tiga perkebunan yang ada di PT. Bumi Palma Lestari Persada, Bumi Lestari Estate berada di areal lahan gambut dengan komoditi utama kelapa sawit, perkebunan Bumi Lestari Estate ini adaah perkebunan yang di miliki perusahaan Sinarmas.

\section{2.2 Letak Geografis}

8. PT. Bumi Palma Lestari Persada terletak di Desa Bagan Jaya Kecamatan Enok Kabupaten Indragiri Hilir Provinsi Riau. Saat pelaksaan magang penulis di letakan di perkebunan Bumi Lestari Estate di Desa Bagan Jaya Kecamatan Enok Kabupaten Indragiri Hilir Privinsi Riau.

a. Perkebunan PT. Bumi Palma Lestari Persada terletak di antara empat Kecamatan yaitu Kecamatan Kempas, Kecamatan Enok, Kecamatan Keritang, Kecamatan Reteh. Di tinjau dari letak geografis PT. Bumi Palma Lestari Persada memiliki perbatasan sebagai berikut : Sebelah utara berbatasan dengan Kecamatan Kempas. Sebelah selatan berbatasan dengan Kecamatan Reteh.

b. Sebelah timur berbatasan dengan Kecamatan Enok.

c. Sebelah barat berbatsan dengan Kecamtan Keritang.

\subsection{Areal Konsensi Dan Tata Guna Lahan}

Perkebunan Bumi Lestari Estate PT. Bumi Palma Lestari Persada mempunyai luas areal 1,657.19 $\mathrm{Ha}$, secara keseluruhan yang terbagi menjadi tiga devisi, termasuk daerah perkantoran, masjid, gudang, puskesmas, serta fasilitas olahraga.

\subsection{Keadaan Iklim Dan Tanah}

Keadaan tanah yang ada di perkebunan PT. BPLP adalah tanah yang kondisinya $100 \%$ gambut dengan $\mathrm{pH}$ tanah 4-5,5 dengan kedalaman sekitar 3-4 meter.

\subsection{Keadaan Tanaman Dan Produksi}

Tanaman yang dibudidayakan adalah tanaman kelapa sawit, dari keseluruhan perkebunan Bumi Letari Estate ini terdiri dari tahun tanam 2011, 2012, 2014, 2015, dan 2016 dengan jarak tanam $8,5 \times 8,5 \times 8,5$ sehingga populasi pokok per hektar adalah 160 pokok dengan melihat tanamannya, perkebunan Bumi Lestari Estate merupakan tanaman menghasilkan.

\section{Struktur Organisasi Dan Ketenagakerjaan}

Perkebunan Bumi Palma Estate PT. Bumi Palma Lestari Persda terdiri dari tiga divisi yang dipimpin oleh seorang Manager Estate, 3 asisten dan 1 kasir. Stuktur organanisasi dan ketenagakerjaan perkebunan Bumi Lestari Estate adalah suatu kerangka yang mempunyai hubungan antara atasan dan bawahan dalam suatu tugas sehingga wewenang dan tanggung jawab menyatu dalam kedaulatan yang teratur. Adapun tanggung jawab dari masing-masing personalisasi dalam struktur organisasi dan ketengakerjaan perkebunan Bumi Lestari Estate sebagai berikut:

1. Estate Manager

Salah satu fungsi manager adalah memeberikan motivasi kepada bawahannya dengan motivasi yang benar maka bawahannya akan bersemangat dalam pencapaian prestasi memperoleh hasil kerja. Tugas pokok seorang managar adalah menggerakan serta mengkoordinasi : man, money, matodhe, machine dan market yang meliputi perencanaan, pelaksaan, pengawasan, dan bertanggung jawab terhadap kinerja suatu estate.

\section{Asiten divisi}

Asisten devisi bertugas membantu manager dalam mengolah divisi untuk melaksakan pekerjaan manajemen tingkat divisi membantu mengawasi tenaga kerja dan melakukan analisis kegiatan lapangan.

\section{Mandor}

Bertugas membantu asisten untuk mengawasi dan memberikan arahan kepada pekerja dlam semua kegiatan yang di lakukan di lapangan serta mandor bertugas menentukan jumlah tenaga kerja dalam kegiatan lapangan.

4. Karyawan tenaga kerja lapangan Karyawan yang melakukan pekerjaan di lapangan sesuai dengan bagiannya masing-masing

\section{METODOLOGI PENELITIAN}

\section{PELAKSAAN KEGIATAN MAGANG}

\subsection{Waktu dan Tempat}

Kegiatan magang ini dilaksanakan selama satu bulan, dimulai pada tanggal 06 Januari sampai dengan 06 Februari 2020 di perkebunan kelapa sawit PT. Bumi Palma Lestari Persada (BPLP), Desa Bagan Jaya Kecamatan Enok Kabupaten Indragiri Hilir Provinsi Riau.

\subsection{Metode Pelaksanaan}

Pada saat melakukan kegiatan magang metode yang dilakukan adalah metode praktek kerja lapangan, kegiatan tersebut melakukan seluruh jenis perkerjaan pada level manajerial yang di izinkan, mulai Karyawan Harian Lepas $(\mathrm{KHL})$, pendamping mandor dan pendamping asisten. 


\subsection{Aspek Teknis}

Aspek tekis adalah bagian di mana semua pekerjaan yang ada di perkebunan tersebut di ikuti oleh penulis dan dilaksanakan bersama karyawan perusahaan, disini penulis menjalankan tugas yang di intruksikan oleh asisten dan mandor serta bertanggung jawab atas semua tugas, atau pu tugas-tugas yang penulis lakukan antara lain : Panen merupakan kegiatan pengambilan buah sawit yang telah masak atau Tandan Buah Segar (TBS) yangmemenuhi kriteria panen, kriteria buah masak diperkebunan PT. Bumi Palma Lestari Persada (BPLP), Desa Bagan Jaya Kecamatan Enok Kabupaten Indragiri Hilir Provinsi Riau adalah sesuar dengan MRS (Minimun Ripeness Standart) yaitunsekurang-kurangnya 5 brondolan per janjang di piringan sebelum panen.

Fokus utama kegiatan adalah memotong semua janjang masak panen rotasi panen normal 7-9 hari dan mutu buah panen sesuai standart, mengutip semua brondolan, serta mengirimkan seluruh TBS yang di panen ke PKS selambatlambatnya dalam waktu $<24$ jam. Hal yang harus di perhatikan adalah tidak ada buah masak yang tertinggal di pohon, tindak ada buah mentah yang di panen, tidak ada brondolan yang tertingal di piringan serta pelepah yang di potong harus di susun rapi di gawang mati. TBS dan brondolan di kumpulkan di tempat pengumpulan hasil (TPH). Dan apabila ada pemanen yang memanen buah mentah, buah panen di tinggal di piringan, buah tidak di susun di TPH serta brondolan maka pemanen tersebut di kenkan denda.

\subsubsection{Brondolan}

Pengutipan brondolan sangat penting, karena brondolan juga memiliki tingkat rendaman minyak yang tertinggi di samping TBS. Buah kelapa sawit yang telah di panen akan menyisakan brondolan di piringan yang akan di kuti oleh pengutip brondolan, dan di letakkan ke tempat pengumpulan hasil (TPH). Setelah itu krani panen akan menghitung hasil brondolan setelah di kutip oleh pengutip brondolan tersebut. Pembersihan Gulma

Pengendalian gulma adalah tindakan untuk mengendalikan pertumbuhan gulma yang tumbuh di areal pertanaman agar persaingan dengan tanaman utama dapat di tekan, gulma yang di basmi berupa gulma berdaun sempit dan berdaun lebar serta anak kayu yang berada disekitar piringan dan gawangan. Tanaman kelapa sawit dengan penyemprotan dan secara manual dengan melakukan pendongkelan dengan menggunkan dodos. Sampel daun adalah kegiatan yang mendukung data rekomendasi pemupukan melalui daun tanaman kelapa sawit, cara kerja dengan memotong pelepah tanaman kelapa sawit, dan pelepah yang di potong adalah pelepah yang ke 17 yang berada ditengah pelepah, kemundian menggunting daun tengah dari pelepah tersebut dengan ukuran sekitar $20 \mathrm{~cm}$.

\subsubsection{Transport TBS}

Transport TBS meliputi bargas container dan poton container. Bargas container adalah alat untuk mengangkat buah yang sudah di panen oleh para pemanen yang ada di TPH.

Di dalam suatu bargas biasanya terdapat 3 orang karyawan yang biasanya berfungsi sebagai operator bargas dan helper, operator bargas adalah orang yang membawa bargas dan helper adalah orang yang mengangkut buah yang ada di TPH dan di masukan kedalam bargas dengan menggunkan tojok. Setelah bargas terisi penuh oleh buah, maka keranjang (kejis) di pindahkan secara mekanis de gan menggunakan RB crane, dalam hal ini keranjang berisi buah dalam bargas langsung di angkat oleh RB crane kedalam Ponton Container (PC). Aspek Manegerial

Pada sebuah perusahaan perkebunan di samping aspek teknis, aspek managerial juga hal yang sangat penting untuk menentukan tujuan yang akan di capai oleh perusahaan tersebut, kegiatan managerial yang telah penulis ikuti selama kegiatan magang di perkebunan PT. Bumi Palma Lestari Persada (BPLP), Desa Bagan Jaya Kecamatan Enok Kabupaten Indragiri Hilir Provinsi Riau adalah sebagai pendamping asisten devisi,dan pendamping mandor.

\section{HASIL DAN PEMBAHASAN}

\section{Hama}

12. Hama adalah organisme yang menginfeksi tanaman dan merusaknya sehingga mengakibatkan penurunan hasilpertanian, perkebunan maupun sayur-sayuran. Infeksi hama dan penyakit secara meluas dapat menimbulkan kerugian yang besar. Oleh karena itu, diperlukan adanya upaya pemberantasan hama(Rukmana, 2003).

4.3. Hama dapat merusak tanaman secara langsung maupun tidak langsung. Hama yang merusak secara langsung dapat dilihat bekasnya, misalnya gerekan dan gigitan. Sedangkan hama yang merusak tanaman secara tidak langsung melalui penyakit yang dibawa hama tersebut. Pertumbuhan dan perkembangan tanaman dari benih, pembibitan hingga pemanenan tidak luput dari gangguan hama.Hama yang menyerang tanaman kelapa sawit adalah: Hama Kumbang Tanduk (Oryctes rhinoceros)

Pada Kelapa Sawit Serangan hama ini cukup membahayakan pada TBM apabila serangan mengenai titik tumbuh tanaman kelapa sawit maka akan mengakibatkan penyakit busuk dan kematian. Kumbang tanduk banyak menimbulkan kerusakan pada tanaman kelapa sawit di areal (Heri Hartanto, 2011). Menurut Susanto dkk (2012), kerugian akibat serangan 0 . 
rhinocerospada perkebunan kelapa sawit dapat terjadi baik secara langsung maupun tidak langsung. Kerugian secara tidak langsung adalah dengan rusaknya pelepah daun yang akan menurunkan produksi. Kerugian secara langsung adalah matinya tanaman kelapa sawit akibat serangan hama ini yang sudah mematikan pucuk tanaman.

Hama ini menyerang bakal daun pada titik tumbuh, masuk melalui pelepah. Kumbang ini menggerek ke dalam kumpulan daun yang akan tumbuh, menyebabkan daun yang keluar menjadi rusak dan menjadi tempat masuknya pathogen yang dapat mematikan tanaman Kelapa Sawit (Vademikum, 2003). Permasalahan hama ini semakin menjadi lebih penting diakibatkan pemberlakuan sistem zero burning pada replanting atau peremajaan tanaman tua. Batang kelapa sawit yang sudah terserang ganoderma tetapi masih tegak berdiri, merupakan tempat yang sangat sesuai untuk perkembangan hamaO.rhinoceros(Susanto dkk, 2012). Teknik Pengendalian 0 . rhinocerosPengendalian $O$. rhinoceros pada perkebunan kelapa sawit menggunakan system pengendalian hama terpadu (PHT). System PHT ini bertumpu pada kegiatan utama yaitu monitoring atau sensus $O$. rhinocerosatau intensitas kerusakan tanaman Sawit. Hasil sensus ini selanjutnya digunakan sebagai dasar pengendlian $O$. rhinoceros. Ada dua cara yang digunakan untuk melakukan monitoring O. rhinocerosyaitu berdasarkan populasi kumbang di lapangandan berdasarkan serangan baru atau intensitas kerusakan baru. Karena keduanya memiliki kelemahan, sebaiknya dilakukan sekaligus pada saat sensus.

Pengendalian Secara Mekanis

Populasi larva hama O. Rhinocerosyang terlalu banyak pada TBM yang tidak memungkinkan untuk dilakukan pengutipan larva maka dapat dilakukan tindakan pengendalian secara fisik dan mekanik dengan menggunakan alat berat. Pada tempattempat yang di curagai sebagai sebagai berkembang biak hama $O$. rhinocerosyang biasanya tandan kosong kelapa sawit, rumpukan batang kelapa sawit, tunggul tanaman lain, serta tanah gambut dilakukan penindasan dengan menggunakan alat berat sekaligus membingkar gundukan yang besar dan selanjutnya dilakukan pengutipan larva secara manual (Susanto dkk,2012).

Pengendalian Secara Kimiawi

Pengendalian kimiawi masih diperlukan dalam pengendalian hama $O$. rhinoceroskarena tidak semua yang ditarik feromon masuk dalam ferotrap. Oleh karena itu penggunaan insektisida untuk tanaman di sekeliling feromon wajibdilaksanakn. Dengan demikina, penggunaan 15 insektisida tidak harus digunakan untuk semua tanaman kelapa sawit (Susanto dkk, 2012). Pengendalian Secara Biologi Pengendalian kumbang tanduk O. rhinocerossecara biologi menggunakan beberapa agensi hayati diantaranya jamur Metarhizium anisopliae dan Baculovirus Oryctes. Unruk aplikasi virus saat ini belum digunakan secara luas di perkebunan kelapa sawit. Jamur M. anisopliaemerupakan jamur parasit yang telah lama digunakan untuk mengendalikan hama O. rhinoceros. Hama Ulat api

merupakan jenis ulat pemakan daun kelapa sawit yang paling sering menimbulkan kerugian di perkebunan kelapa sawit.Disebut ulat api karena punggungnya berbulu kasar kaku dan beracun racunnya keluar dari bulu kasar tersebut berupa cairan yang jika terkena tanganterasa gatal dan panas Jenis-jenis ulat api yang paling banyak ditemukan adalah Setothosea asigna, Setora nitens, Darna trima, Darnadiducta danDarna bradleyi. Jenis yang jarang ditemukan adalah Thosea vestusa, Thosea bisura, Susica pallida danBirthamula chara. Jenis ulat api yang paling merusak di Indonesia akhir-akhir ini adalah $\mathrm{S}$. asigna, S. nitens danD. trima(Wikipedia, 2012)

Gejala ulat api Kerusakan Yang Disebabkan Ulat ApiGejala serangan dari berbagai macam ulat api hampir sama yaitu melidinya daun kelapa sawit apa bila serangan berat. Serangan Setothosea asigna dilapangan umumnya mengakibatkna daun kelpa sawit habis dengan sangat cepat dan berbentuk seperti melidi. Tanaman tidak dapat menghasilkan tandan selama 2-3 tahun jika serangan yang terjadi sanagat berat. .Pengendalain hama ulat api

$\checkmark \quad$ Cara biologisPengendalian biologis, secara alami terdapat sejumlah musuh alami, tetapi umumnya pemanfaatannya masih perlu dikembangkan. Untuk jenis-jenis parasit atau predator terhadap ulat api parasit nya adalah parasit telur Ttrichogrammatoideathosease, parasit larva Gariphus maculipennis, Spinaria spinator, parasi kepompong Chatoescorista javana,sedangkan jenis jenis predatornya antara lain predator larva Sycanus dichotomus.

4.6. Cara kimiawi Pengendalian kimiawi dapat dilakukan dengan penyemprotan atau injeksi batang. Penyemprotan dapat dilakukan dari darat atau dari udara. Pada pengendalian kimiawi perlu dipilih jenis-jenis insektisida yang efektif tetapi aman bagi SPKS maupun musuh-musuh alami dari hama. Jenis-jenis yang dianjurkan dengan cara penyemprotan adalah antara lain yang berbahan aktif dari kelompok penghambat kitin(chitin inhibitor) antara lain yang mempunyai bahan aktif diflubenzuron (Dimilin). Hama Rayap

Rayap (Coptotermes curvignathus) merupakan serangga yang potensial menjadi hama tanaman perkebunan dan dapat menimbulkan permasalahan yang serius pada perkebunan kelapa sawit yang baru dibuka, ini disebabkan masih banyaknya dijumpai pangkal batang kayu mati dan bekas tanaman hutan di areal tersebut yang dapat memberikan kesempatan pada rayap untuk hidup 
dan berkembang biak Saat kayu tersebut habis, maka rayap akan mencari sumber makanan yang baru termasuk tanaman kelapa sawit (Prasetiyo. Dan Yusuf, 2005).Cara rayap menyerang tanaman kelapa sawit Rayap pekerja menggerek dan memakan pangkal pelepah, jaringan batang, akar dan pangkal akar, daun serta titik tumbuh tanaman kelapa sawit. Serangan berat dapat menyebabkan kematian bibit maupun tanaman dewasa di lapangan.

\section{Gejala tanaman kelapa sawit yang terserang} rayap :

1. Adanya lorong rayap yang terbuat dari tanah yang berada di permukaan batang yang mengarah ke bagian atas.

2. Terlihat daun pupus layu dan kering.

3. Banyak rayap berkeliaran di sekitar tanaman Pengendalian rayap secara manul

Cara pengendalian rayap yang efektif adalah dengan menghancurkan sarangnya danmembunuh semua anggota koloni rayap terutama ratu. Akan tetapi di areal tanaman kelapa sawit yang terserang, terutama di areal gambut, sulit untuk menemukan sarang rayap. Oleh sebab itu, upaya pengendalian saat ini lebih ditekankan untuk membunuh rayap yang menyerang pokok kelapa sawit, serta mengisolasi pokok yang terserang agar hubungan antara pokok dengan sarang rayap dapat diputus. Hal ini dianggap perlu, karena rayap baru akan selalu datang dari sarangnya ke pokok terserang untuk menggantikan rayap yang mati.

\section{Pengendalian Rayap secara kimia}

Insektisida yang direkomendasikan untuk pengendalian rayap seperti pada Tabel

1. Regent 50 SC berbahan aktif Fipronil dengan dosisi aplikasi 2,50 ml/l air

2. Termiban 400 EC berbahan aktif Chlorpyriphos dengan dosisi aplikasi 6,25 ml/l air

Demikian informasi tentang cara pengendlaian rayapa di perkebunan kelapa sawit. semoga bermanfaat.

\section{KESIMPULAN DAN SARAN}

Hama adalah organisme yang dianggap merugikan dan tak diinginkan dalam kegiatan sehari-hari manusia. Walaupun dapat digunakan untuk semua organisme, dalam praktek istilah ini paling sering dipakai hanya kepada hewan. Suatu hewan juga dapat disebut hama jika menyebabkan kerusakan pada ekosistem alami atau menjadi agen penyebaran penyakit dalam habitat manusia. Serangga merupakan kelompok hewan yang dominan di muka bumi dengan jumlah spesies hampir 80 persen dari jumlah total hewan di bumi. Dari 751.000 spesies golongan serangga, sekitar 250.000 spesies terdapat di Indonesia. Serangga di bidang pertanian banyak dikenal sebagai hama
(Kalshoven 1981). Sebagian bersifat sebagai predator, parasitoid, atau musuh alami (Christian \& Gotisberger 2000).

Banyak Hama yang menyerang tanaman kelapa sawit sehingga hama merugikan secara ekonomis, jenis-jenis hama yang menyerang tanaman kelapa sawit antara lain tungau, ulat api, kubang badak, kumbang moncong, penggerek tandan buah.

\subsection{Saran}

Untuk memperkecil adanya penyimpangan atau kesalahan teknis dilapangan dalam kegiatan pemupukan, sebaiknya pengawasan lebih diperketat dari segala aspek.

\section{DAFTAR PUSTAKA}

1. Chan.f.Dan Suwandi,(1982). Aspek Ekonomis Tanaman Kelapa Sawit. Jakarta

2. Rukmana, Rahmat. 2003. Usaha Tani Kapri. Yogyakarta: sPenerbit KanisiusLubis, (1992). Kelapa Sawit, Balai Penelitian.

3. Hartanto, Heri. 2011. Sukses Besar Budidaya Kelapa Sawit. Citra Media Publishing.

4. Yogyakarta.Mongoensokarjo, (2007). Keterswdiaan Unsur Hara. Pustaka. Purwokerto

5. Susanto. 2012. Pengendalian Terpadu Oryctes rhinocerosdi Perkebunan Kelapa sawit. PPKS Medan

6. Wikipedia. 2012. Kelapa sawit. http:// www.Sejarahkelapa sawit.Com (diakses 08/11/2012).

5. Prasetyo dan Yusuf, 2005. Khitosan Alternatif Pengendali Rayap Ramah Lingkungan, Rineka Cipta, Jakarta. 